\title{
Effects of Milk Replacer Composition on Selected Blood Metabolites and Hormones in Preweaned Holstein Heifers
}

\author{
K. M. Daniels, S. R. Hill, K. F. Knowlton, R. E. James, M. L. McGilliard, and R. M. Akers ${ }^{1}$ \\ Department of Dairy Science, Virginia Polytechnic Institute and State University, Blacksburg 24061
}

\begin{abstract}
We investigated the effects of increasing dietary protein and energy on concentrations of selected blood metabolites and hormones in Holstein heifers. Twentyfour heifers were fed 1 of 4 milk replacer (MR) diets for $9 \mathrm{wk}(\mathrm{n}=6 /$ diet): control [20\% crude protein $(\mathrm{CP}), 21 \%$ fat MR fed at $441 \mathrm{~g}$ of dry matter (DM)/d], HPLF (28\% $\mathrm{CP}, 20 \%$ fat MR fed at $951 \mathrm{~g}$ of DM/d), HPHF (27\% CP, $28 \%$ fat MR fed at $951 \mathrm{~g}$ of $\mathrm{DM} / \mathrm{d})$, and $\mathrm{HPHF}+(27 \%$ $\mathrm{CP}, 28 \%$ fat $\mathrm{MR}$ fed at $1,431 \mathrm{~g}$ of $\mathrm{DM} / \mathrm{d})$. Heifers were fed twice daily; water and starter (20\% CP, $1.43 \%$ fat) were offered free choice and starter orts recorded daily. Serum and plasma aliquots from blood samples collected twice weekly after a 12-h fast were analyzed for insulin-like growth factor (IGF)-I, IGF-binding proteins (IGFBP), growth hormone (GH), insulin, glucose, nonesterified fatty acids, triglyceride, and plasma urea nitrogen concentrations. Only plasma glucose, IGFBP-2, and IGFBP-3 were affected by diet. Dietary treatment differences were only noted when the control was compared with the average of the other 3 diets. The addition of fat to the MR (HPLF vs. HPHF) and increased volume of MR (HPHF vs. HPHF+) had no effect on plasma glucose concentration or relative abundance of IGFBP2 or IGFBP-3. Heifers fed the control diet had less glucose, greater IGFBP-2, and less IGFBP-3 than the average of the other 3 diets. There was a diet by week interaction for IGF-I. Serum IGF-I concentration in control heifers varied in a quadratic manner with a nadir $(20 \pm 4 \mathrm{ng} / \mathrm{mL})$ at wk 4 , whereas IGF-I increased linearly in heifers on other diets. Both insulin and triglyceride changed over time in a complex pattern (significant linear and quadratic contrast effects). The greatest concentrations were measured at wk 0.5 with nadirs at wk 6 for both insulin and triglyceride. Serum GH concentration decreased in a linear manner from wk 0.5 to wk 9 in all heifers. Relative abundance of IGFBP-2 was quadratic over time with the greatest amount of
\end{abstract}

Received November 13, 2007.

Accepted February 29, 2008.

${ }^{1}$ Corresponding author: rma@vt.edu
IGFBP-2 observed at wk 5. With the exception of glucose, IGF-I, IGFBP-2, and IGFBP-3, the blood variables measured were not influenced by treatment. The IGF-I -GH-IGFBP axis requires further study in heifers to deduce effects of nutrition on hypothalamic regulation of metabolism. We expected to see more treatment differences in concentrations of metabolites involved with protein and fat metabolism. It is likely that the diets used in this study were not diverse enough in composition to elicit such changes or that the efficiency of use of absorbed protein and fat was not different in these animals.

Key words: blood metabolite, dairy calf, milk replacer

\section{INTRODUCTION}

Many researchers have sought to understand mechanistic relationships between protein and energy intakes and accretion of body tissue in Holstein heifers fed various whey protein-based milk replacers (MR; Diaz et al., 2001; Brown et al., 2005a; Bartlett et al., 2006). However, the anticipated changes in concentrations of circulating hormones and metabolites to explain dietary-induced differences in growth or tissue accretion has received limited attention. Moreover, recent efforts to lower age at first calving and thus the period of nonproductive life of replacement heifers has led many producers to maintain their animals on high-gain diets (BW gains of $>700 \mathrm{~g} / \mathrm{d}$ ) particularly after weaning during the prepubertal phase of life. This practice is known to increase rates of skeletal and BW growth but may also negatively impact mammary development in at least some circumstances (Sejrsen and Purup, 1997; Sejrsen et al., 2000; Brown et al., 2005b; Meyer et al., 2006a,b). Much less is known about the effect of rate of gain or specific dietary components on mammary development or subsequent lactation performance in heifers before weaning. This work was conducted to address this need and to allow a more comprehensive evaluation in concert with measures of growth, body composition, and mammary development (reported in Hill et al., 2008). In this paper, we provide data for effects of feeding varying protein and energy via use of commercially available and specially formulated calf 
MR coupled with ad libitum starter intake on concentrations of selected blood metabolites and hormones. We also report common measures of calf performance (fecal scores, hematocrit, general health) for these heifers.

A major focus is the impact of energy and protein intake on the growth hormone (GH)-IGF-1 axis as others have emphasized (Breier et al., 1988; Hammon and Blum, 1997; Smith et al., 2002). This is because of wellrecognized effects of these molecules on nutritional physiology, body growth, and mammary development. Growth hormone concentration is typically reduced and IGF-I elevated in well-fed heifers. However, the activity of IGF-I is regulated by IGF binding proteins (IGFBP). Irrespective of diet, both IGF-I and GH are temporally regulated in heifers, with circulating $\mathrm{GH}$ concentration greater in neonates but reduced in postnatal life. We sought to measure circulating GH, IGF-I, and IGFBP in heifers fed different diets to evaluate these temporal and nutritional relationships and additionally associate changes with calf performance and measures of growth and body composition reported in Hill et al. (2008).

Blood metabolites are traditional and accepted indicators of nutritive status and metabolism. Diaz et al. (2001) suggested that altering the carbohydrate and fat content of MR might increase the biological value of absorbed protein. We hypothesized that regulators of carbohydrate, protein, and lipid metabolism such as the GH-IGF-I axis molecules would be affected by our dietary treatments and that these alterations would be mirrored by changes in concentrations of circulating hormones and metabolites. We also anticipated that changes in these hormones and metabolites would correspond with heifer performance. We chose to measure serum total protein and plasma urea nitrogen (PUN) to evaluate protein metabolism and NEFA and triglyceride concentrations as indices for fat metabolism.

In preweaned heifers, glucose and insulin concentrations are typical of mammalian monogastrics, whereas concentrations of VFA are proportionally reduced but increase with time and starter intake. In older ruminants both glucose and insulin concentrations are reduced whereas VFA concentrations are proportionally increased. Quigley et al. (1991) demonstrated that plasma glucose declined with age and also with early weaning. We expected that differences would be evident in glucose and insulin concentrations in heifers fed various MR formulations coupled with ad libitum starter intake and that these differences would be associated with DMI.

The objectives of this experiment were to investigate effects of altering dietary protein and energy on concentrations of selected blood metabolites and hormones in Holstein heifers between 1 and 9 wk of age. A secondary objective was to examine the relationship between concentrations of metabolites and hormones with overall calf performance.

\section{MATERIALS AND METHODS}

\section{Animals and Management}

Heifers and Housing. The Virginia Tech Animal Care and Use Committee approved the following animal procedures. This study was designed as a randomized complete block experiment. Twenty-four Holstein heifer calves were acquired from a commercial dairy farm within $3 \mathrm{~d}$ of birth $(40.4 \pm 2.2 \mathrm{~kg}$ of BW) and blocked into groups of 8 by the order acquired. Arrival dates for the 3 groups were August 20, September 10, and September 25, 2005. At the commercial dairy, all calves received $1.89 \mathrm{~L}$ of thawed colostrum as soon as possible after birth via nipple bottle. Colostrum was previously collected from multiparous dairy cows at the Virginia Tech Dairy Center, pooled, and frozen in 1.89$\mathrm{L}$ aliquots in plastic bags. Six to $12 \mathrm{~h}$ after birth, all animals were fed a commercial colostrum replacement (Bovine IgG Colostrum Replacement, Land O'Lakes Inc. Animal Milk Products Co., Arden Hills, MN). The entire contents of one packet $(471 \mathrm{~g})$ was poured into $1.89 \mathrm{~L}$ of 43 to $49^{\circ} \mathrm{C}$ water, mixed, and fed by nipple bottle. Any additional feedings at the cooperating dairy consisted of twice-daily feedings (1.89 L) of a $20 \% \mathrm{CP}$, $21 \%$ fat MR (Land O'Lakes Inc. Animal Milk Products Co.) via nipple bottle. Morning feedings were supplemented with $30 \mathrm{~g}$ of Gammulin (APC Inc., Ames, IA) mixed with MR. Immediately before and after travel to the Virginia Tech Dairy Center, all calves were offered $1.89 \mathrm{~L}$ of warm electrolytes (Travel-Lyte, Nouriche Nutrition Ltd., Lake St. Louis, MO).

Upon arrival at the Virginia Tech Dairy Center, subcutaneous injections of $4 \mathrm{~mL}$ of Excenel (Pharmacia and Upjohn Company, Kalamazoo, MI), $3 \mathrm{~mL}$ of BoSe ( $1 \mathrm{mg}$ of selenium and $68 \mathrm{IU} / \mathrm{mL}$ of vitamin $\mathrm{E}$, ScheringPlough Animal Health Corp., Union, NJ), $1 \mathrm{~mL}$ of vitamins A and D (500,000 IU/mL of vitamin A; 75,000 IU/ $\mathrm{mL}$ of vitamin $\mathrm{D}$, Vedco Inc., St. Joseph, MO) were administered. Additionally, all animals received an intranasal dose of $2 \mathrm{~mL}$ of TSV-2 (Pfizer Animal Health, New York, NY); at $9 \mathrm{~d}$ all animals received an intramuscular injection of $2 \mathrm{~mL}$ of Pyramid 4 (Fort Dodge Animal Health, Overland Park, KS).

Heifers were individually housed in open hutches bedded with loose gravel for wk 1 through 8 . At wk 9 they were moved to individual metabolism stalls for total collection of feces and urine (Hill et al., 2008). One heifer (group 1; on high-protein, low-fat MR) died unexpectedly at $6 \mathrm{wk}$ of age from acute peritonitis and endotoxemia that resulted from a perforated abomasal 
Table 1. Ingredient and nutrient composition of milk replacers varying in protein and fat content fed to Holstein heifers ${ }^{1}$

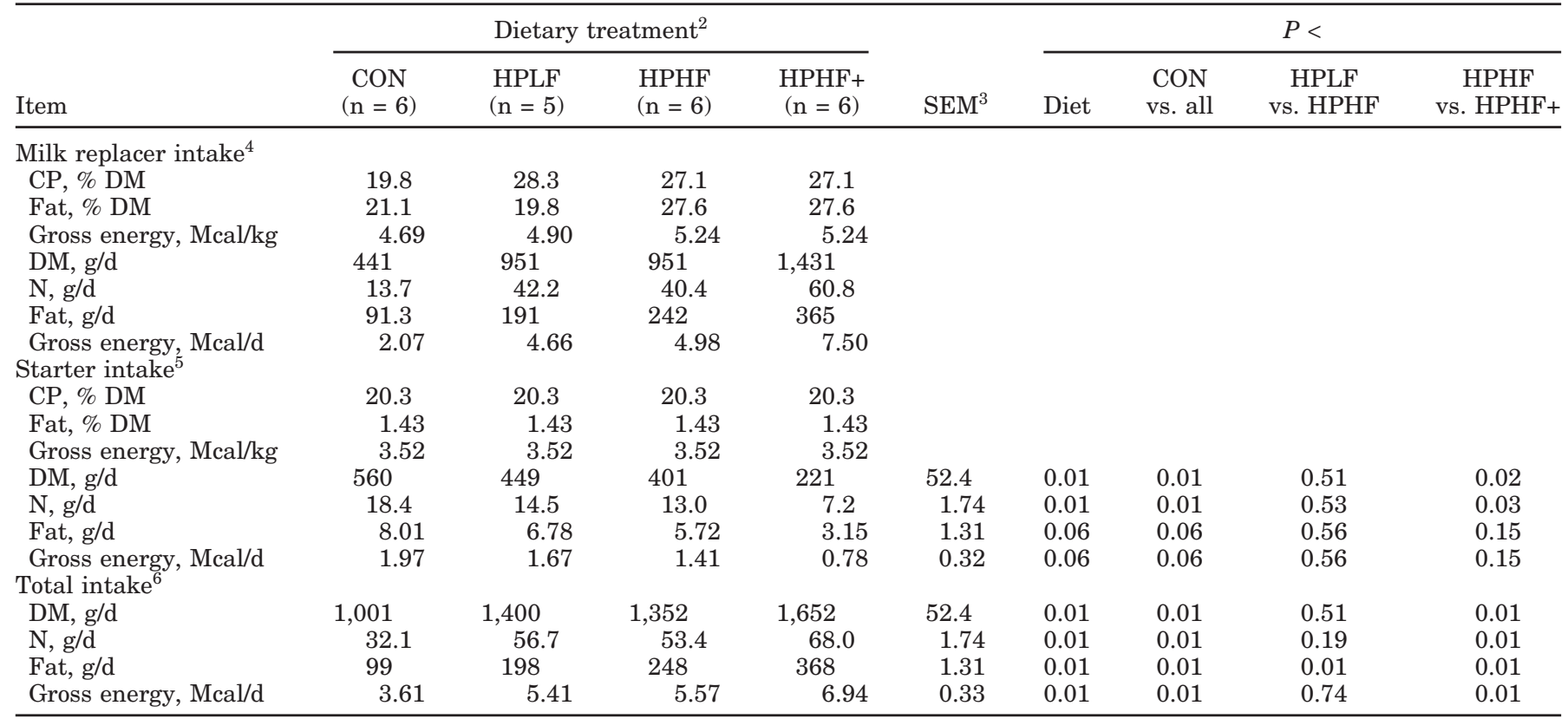

${ }^{1}$ Adapted from Hill et al., 2008.

${ }^{2} \mathrm{CON}=$ control milk replacer (MR) with $20 \% \mathrm{CP}$ and $21 \%$ fat, fed at $441 \mathrm{~g}$ of DM/d; HPLF = high-protein, low-fat MR with $28 \% \mathrm{CP}$ and $20 \%$ fat, fed at $951 \mathrm{~g}$ of DM/d; HPHF = high-protein, high-fat MR with $27 \% \mathrm{CP}$ and $28 \%$ fat, fed at $951 \mathrm{~g}$ of DM/d; HPHF+ = HPHF fed at $1,431 \mathrm{~g}$ of $\mathrm{DM} / \mathrm{d}$.

${ }^{3}$ Standard error of the mean for diet; highest listed.

${ }^{4}$ No statistical analysis was completed because within treatment, equal amounts were fed daily and probability of difference could not be calculated.

${ }^{5}$ Starter contained $44.4 \%$ ground corn grain, $44.4 \%$ soybean meal, $11.2 \%$ cottonseed hulls, and $1.0 \%$ dried molasses.

${ }^{6}$ Total intake $=$ MR plus starter.

ulcer; that animal was not replaced and data from her were excluded. All animals were sacrificed at approximately $64 \mathrm{~d}$ of age to evaluate mammary development and body composition (K. M. Daniels, unpublished data; Hill et al., 2008). At the time of slaughter, it was noted that a heifer (group 3; on control MR) had an irregularly shaped reproductive tract and underdeveloped mammary tissue. This heifer was suspected to be a freemartin; her hormone and metabolite data were retained. Additionally, just before harvest, 2 other calves (group 1 ; on high-protein, high-fat MR fed at the higher rate) showed symptoms of urinary tract infection, were treated with intravenous fluids and antibiotics, and survived until harvest.

Diets and Feeding. Dietary MR treatments were randomly assigned within each group. The MR treatments used in this trial were control (CON; 20\% CP, $21 \%$ fat MR fed at $441 \mathrm{~g}$ of DM/d), high-protein/low-fat MR (HPLF; 28\% CP, 20\% fat MR fed at $951 \mathrm{~g}$ of DM/ d), high-protein/high-fat MR (HPHF; 27\% CP, $28 \%$ fat MR fed at $951 \mathrm{~g}$ of DM/d), and HPHF MR fed at a higher rate (HPHF+; 27\% CP, 28\% fat MR fed at 1,431 g of DM/ d). Analyzed values of MR and average daily intakes are reported in Table 1. All MR powders used in the experiment were obtained from Land O'Lakes Inc. Animal Milk Products Co., were nonmedicated, and contained whey protein as the protein source. Animal tallow was the fat source used in all MR. Animals were fed MR treatment diets reconstituted to $12.5 \%$ solids at 0700 and $1900 \mathrm{~h}$ from nipple buckets. Total volume of the HPHF MR was increased 1.5 fold to increase intake in heifers fed HPHF+. Heifers were offered fresh water and starter free choice. Calf starter $(20 \% \mathrm{CP}$, $1.43 \%$ fat) comprised ground corn $(44.4 \%), 48 \% \mathrm{CP}$ soybean meal (44.4\%), cottonseed hulls (11.2\%), and molasses $(1.0 \%)$. Starter orts were recorded daily at the evening feeding. Milk replacer refusals, if any, were recorded at each feeding. Dietary MR treatments commenced at the morning feeding the day after arrival; if heifers were less than $1 \mathrm{~d}$ old they received one additional feeding of a $20 \% \mathrm{CP}, 21 \%$ fat MR before switching to their assigned treatment diet. All heifers received $30 \mathrm{~g} / \mathrm{d}$ of Gammulin powder (APC Inc.) in the morning milk replacer through $10 \mathrm{~d}$ of age.

Health Monitoring. Fecal and respiratory scores were recorded before the morning feeding throughout the trial according to the methods of Diaz et al. (2001). Briefly, a 4-point scale was used for fecal scoring. A 
fecal score of 1 represented firm, well-formed feces, whereas a score of 4 denoted liquid feces with splatter. Electrolytes (C.H.E.E.R.S, Nouriche Nutrition Ltd.) were offered before the morning feeding to all heifers with a fecal score of 3 or greater, and again at noon to heifers with a fecal score of 4 . Milk replacer was never withheld from scouring animals. Respiratory scores were assigned according to the 6-point scale of Diaz et al. (2001; data not shown). Rectal body temperatures were recorded for each animal for the first $7 \mathrm{~d}$ after arrival, and thereafter only when an animal exhibited abnormal respiratory symptoms. General animal health was monitored several times per day; health incidents (other than scours) were treated according to veterinary instructions.

\section{Blood Collection and Analysis}

Initial IgG Determination. A single jugular blood sample was drawn from each animal upon arrival to determine IgG concentrations in serum as an indicator of passive immunity. Single radial immunodiffusion kits (VMRD Inc., Pullman, WA) were used to measure IgG. Samples were run in duplicate in a single assay; the intraassay CV was $12 \%$.

Blood Collection and Processing. Blood was collected from each animal on Wednesdays and Saturdays before the morning feeding (after a 12-h fast). Jugular blood samples ( $\sim 25 \mathrm{~mL}$ total) were collected into evacuated tubes containing sodium heparin and sodium fluoride, and a tube with no anticoagulant. All samples were kept on ice after collection and were transported to the laboratory within $1 \mathrm{~h}$. Immediately after arrival at the laboratory, aliquots of sodium-heparinized blood $(\sim 30 \mu \mathrm{L})$ were used for determination of packed cell volume (PCV) via the microhematocrit method. The remaining portion of the sodium heparin samples and the sodium fluoride samples were centrifuged at 2,000 $\times g$ at $4^{\circ} \mathrm{C}$ for $20 \mathrm{~min}$. After centrifugation, plasma was decanted into individually labeled $12-\times 75-\mathrm{mm}$ polypropylene tubes, and stored in a $-20^{\circ} \mathrm{C}$ freezer for future analyses of PUN (sodium heparin samples) and glucose (sodium fluoride samples). Tubes without anticoagulant were allowed to clot at room temperature for 3 to $6 \mathrm{~h}$, after which time they were placed in a $4^{\circ} \mathrm{C}$ refrigerator for $24 \mathrm{~h}$. Tubes were then centrifuged at $2,000 \times \mathrm{g}$ at $4^{\circ} \mathrm{C}$ for $20 \mathrm{~min}$; serum was decanted into individually labeled $12-\times 75-\mathrm{mm}$ polypropylene tubes, and stored at $-20^{\circ} \mathrm{C}$ for future analyses of IGF-I, GH, insulin, IGFBP, total protein, NEFA, and triglycerides (TRI).

Hormone and IGFBP Analyses. Serum IGF-I, GH, and insulin concentrations were determined in all samples via double-antibody RIA. For the IGF-I assay, acid- ethanol extraction of binding proteins (Sharma et al., 1994) preceded RIA. Insulin and GH assays were conducted as in McFadden et al. (1990); the IGF-I assay was performed according to Weber et al. (1999) and Berry et al. (2003). Briefly, for the IGF-I assay recombinant human IGF-I (GrowPrep, Adelaide, Australia) was used for iodination and standards. Mouse anti-human IGF-I primary antibody was a gift from Bernard Laarveld (University of Saskatchewan, Saskatchewan, Canada) and was used at a final dilution of 1:70,000. Commercial goat anti-mouse secondary antibody (Sigma Chemical Company, St. Louis, MO) was used at a final dilution of 1:20. For the GH assay, recombinant bovine GH (lot 6958C-42A, American Cyanamid Company, Princeton, NJ) was used for standards and iodination. Rabbit anti-ovine GH (NIDDK-anti-oGH-2; AFPC0123080; gift from the National Hormone and Pituitary Program, Baltimore, MD) was used as the primary antibody at a final dilution of 1:100,000. Ovine antirabbit gamma globulin antiserum was used at a final dilution of 1:15. For the insulin assay, purified bovine insulin (lot 615-70N-80; Eli Lilly and Co., Indianapolis, IN) was used for iodination and standards. Guinea pig anti-bovine insulin (lot GP20) was the primary antibody (Miles Laboratory, Elkhart, IN) and used at a final dilution of 1:12,000. Ovine anti-guinea pig gamma globulin antiserum was used at a final dilution of 1:20. Intra- and interassay CV were less than 8 and $8 \%$ for the IGF-I RIA, 8 and $10 \%$ for the GH RIA, and 9 and 9\% for the insulin RIA.

Western ligand blotting of wk 1, 5, and 9 (Saturday) serum samples was used to determine relative abundance of IGFBP and was performed essentially according to Berry et al. (2003). Briefly, a molecular weight marker (Precision Plus Protein Standards, BioRad Laboratories, Hercules, CA), $16 \mu \mathrm{g}$ of purified IGFBP-3, $4 \mu \mathrm{L}$ of a calf serum pool, and 6 serum samples $(6 \mu \mathrm{L}$ per lane in duplicate) were run in 15 lanes on a vertical slab gel unit (Hoefer Scientific Instruments, San Francisco, CA). Two gels were electrophoresed at the same time. Samples were dissolved into nonreducing SDS-PAGE buffer and electrophoresed through $12 \%$ SDS-PAGE gel at $65 \mathrm{~V}$ for $18 \mathrm{~h}$. After electrophoresis, proteins were electrotransferred $(55 \mathrm{~V}$, $5 \mathrm{~h}$ ) to nitrocellulose membranes and incubated in ${ }^{125} \mathrm{I}$ IGF-I $\left(1 \times 10^{6} \mathrm{cpm} / \mathrm{mL}\right)$ overnight and washed in Trisbuffered saline to remove unbound ligand. Blots were exposed to Kodak x-ray film for $24 \mathrm{~h}$ at $-80^{\circ} \mathrm{C}$. Scanning densitometry was used to quantify changes in IGFBP profiles. Purified IGFBP-3 and an aliquot of a serum pool served as positive controls on each gel.

Biochemical Analyses. Serum total protein quantification was based on the Biuret color reaction (Total Protein Biuret Reagent Set, Pointe Scientific Inc., Can- 
Table 2. Initial immunoglobulin G concentrations in Holstein heifers by diet assignment

\begin{tabular}{lccccccccc}
\hline & \multicolumn{4}{c}{ Diet $^{1}$} & & \multicolumn{3}{c}{ Test of fixed effects, $P$-value } \\
\cline { 2 - 4 } Item & CON & HPLF & HPHF & HPHF+ & SEM $^{2}$ & & Diet & Group & Diet $\times$ group \\
\hline IgG, mg/dL & 1,788 & 1,385 & 1,821 & 2,182 & 475 & 0.666 & 0.192 & 0.327 \\
\hline
\end{tabular}

${ }^{1} \mathrm{CON}=$ control milk replacer $(\mathrm{MR})$ with $20 \% \mathrm{CP}$ and $21 \%$ fat, fed at $441 \mathrm{~g}$ of DM/d; HPLF = high-protein, low-fat MR with $28 \% \mathrm{CP}$ and $20 \%$ fat, fed at $951 \mathrm{~g}$ of DM/d; HPHF = high-protein, high-fat MR with $27 \%$ $\mathrm{CP}$ and $28 \%$ fat, fed at $951 \mathrm{~g}$ of DM/d; HPHF+ = HPHF fed at $1,431 \mathrm{~g}$ of $\mathrm{DM} / \mathrm{d}$.

${ }^{2} \mathrm{SEM}=$ standard error of the mean for diet; highest listed.

ton, MI) and was scaled for use in a 96-well microtiter plate. An aqueous protein standard ( $8 \mathrm{~g} / \mathrm{dL}$, Pointe Scientific Inc.) was used in the assay. Intra- and interassay $\mathrm{CV}$ for serum total protein were less than 3 and 3\%, respectively. Serum TRI were determined using an enzymatic assay kit (Triglycerides-GPO Reagent Set, Pointe Scientific Inc.) with volumes scaled for use in a 96-well microtiter plate. An aqueous triglyceride standard (200 mg/dL, Pointe Scientific Inc.) was used in the assay. Intra- and interassay CV for serum TRI were less than 5 and $8 \%$ respectively. Plasma glucose was analyzed by enzymatic determination (Autokit Glucose, Wako Diagnostics, Richmond, VA) using the Wako Glucose $\mathrm{C} 2$ Microtiter procedure. Intra- and interassay CV for plasma glucose were less than 4 and 3\%, respectively. Plasma urea nitrogen was determined according to the method of Chaney and Marbach (1962) as modified by Weatherburn (1967), except that urease concentration was 10 -fold greater than recommended. Intraand interassay CV for PUN were less than 4 and 4\%, respectively. Plasma NEFA were analyzed by enzymatic determination using NEFA $\mathrm{C}$ kits purchased from Wako Chemicals and the Wako NEFA C Microtiter procedure. Intra- and interassay CV for plasma NEFA were less than 2 and $2 \%$, respectively.

\section{Statistical Analyses}

Initial IgG concentration data were analyzed using the Mixed procedure of SAS (SAS Version 9.1.3, SAS Institute, Cary, NC); diet, group, and their interaction were the fixed effects and heifer within diet and group was the random term.

Hormone and metabolite data were analyzed using the Mixed procedure of SAS with repeated measures. The repeated measure was week and the subject used in tests was heifer within diet and group. An autoregressive covariance structure [AR(1)] was used throughout analyses; no denominator degrees of freedom approximation method was specified. Twiceweekly hormone and metabolite data were averaged within week before analyses in all weeks except wk 0 . Zero-week samples were not averaged because animals were not on their treatment diets for half of the week; wk 0 then represents data from a single blood draw obtained within $2 \mathrm{~d}$ of treatment initiation, and is referred to as wk 0.5. Data are reported as least squares means \pm standard errors. The interaction of group and week and the 3 -way interaction of diet by group by week were considered, but were removed from the final model due to lack of significance. Preplanned nonorthogonal contrast statements were used to examine diet differences when present; they were CON vs. all other treatments; HPLF vs. HPHF; and HPHF vs. HPHF+. Group means were separated with a Tukey test. Orthogonal polynomial contrasts were used to test for linear and quadratic responses over time. The correlation procedure of SAS was used to determine relationships of selected variables. Significance was declared at $P<0.05$ for all procedures. The following model statement was used for all analyses:

$\mathrm{Y}_{\mathrm{ijkl}}=\mu+\mathrm{D}_{\mathrm{i}}+\mathrm{G}_{\mathrm{j}}+\mathrm{W}_{\mathrm{k}}+(\mathrm{DG})_{\mathrm{ij}}+(\mathrm{DW})_{\mathrm{il}}+\mathrm{H}_{(\mathrm{ij}) l}+\mathrm{e}_{(\mathrm{ijk}) l}$

where $\mathrm{Y}_{\mathrm{ijkl}}=$ dependent variable; $\mu$ = overall mean; $\mathrm{D}_{\mathrm{i}}=$ fixed effect of diet $(i=1, . ., 4) ; \mathrm{G}_{\mathrm{j}}=$ fixed effect of group $(\mathrm{j}=1,2,3) ; \mathrm{W}_{\mathrm{k}}=$ fixed effect of week $(\mathrm{k}=1, \ldots, 10)$ (IGFBP, $\mathrm{k}=1,2,3) ; \mathrm{H}_{(\mathrm{ij}) 1}=$ random effect of heifer within diet and group; $(\mathrm{DG})_{\mathrm{ij}}=$ fixed interaction of diet and group; $(\mathrm{DW})_{\mathrm{il}}=$ fixed interaction of diet and week; and $\mathrm{e}_{(\mathrm{ijk}) 1}=$ residual error (assumed to be random and independently distributed).

\section{RESULTS}

\section{Initial IgG Concentrations}

Initial IgG concentrations were not different across diets or groups and averaged 1,809 mg/dL. Failure of passive transfer $(\mathrm{IgG}<800 \mathrm{mg} / \mathrm{dL})$ was detected in 5 heifers (Table 2). These consisted of 3 heifers in group $2(\mathrm{CON}, \mathrm{HPLF}$, and $\mathrm{HPHF}+)$ and 2 heifers in group 3 (CON and HPHF).

\section{Diet by Week Effects}

There was a diet by week interaction for IGF-I $(P=$ 0.044). Serum IGF-I concentration in heifers that con- 


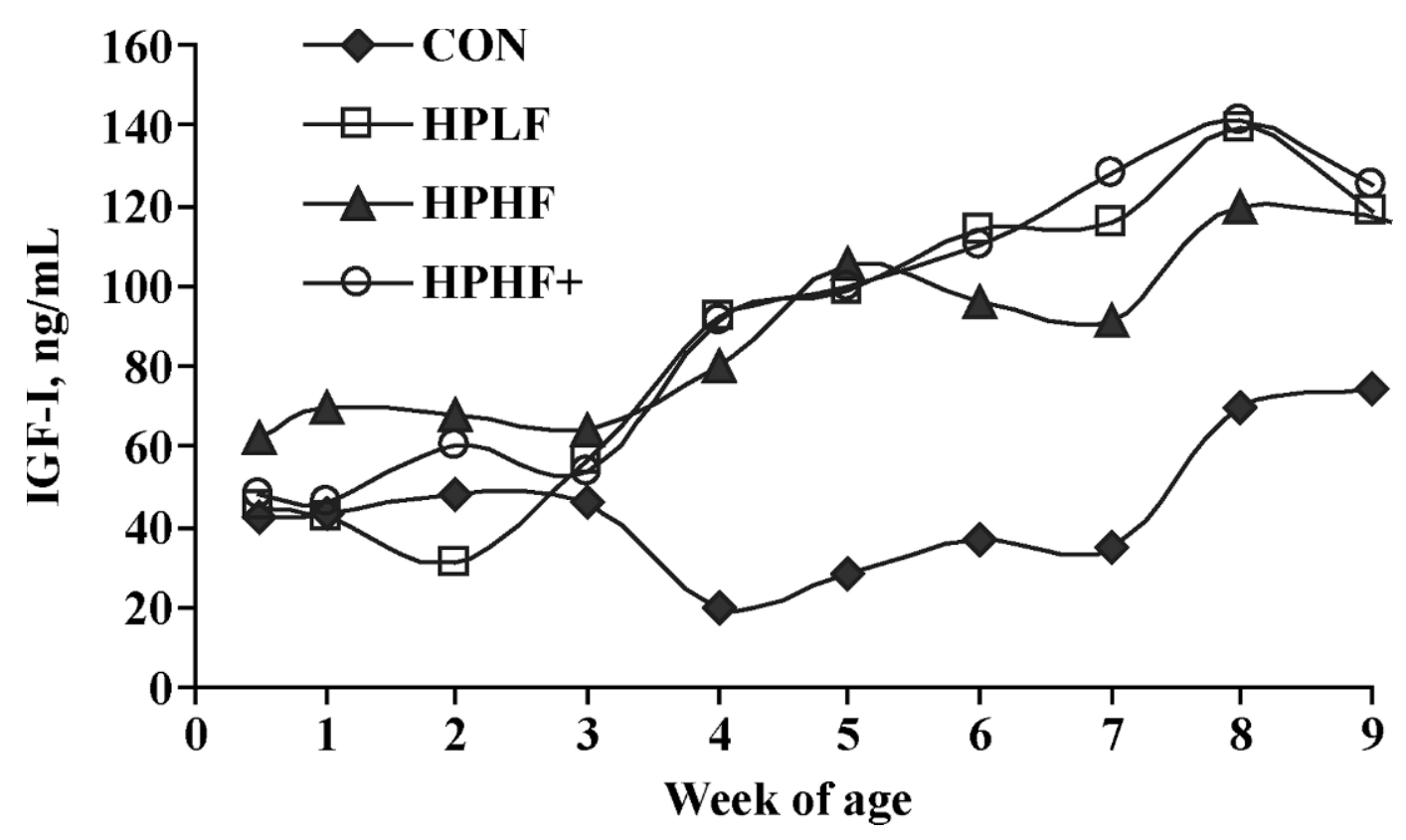

Figure 1. Weekly preprandial serum IGF-I concentration of Holstein heifers fed 1 of 4 treatment diets [CON = control milk replacer (MR) with $20 \% \mathrm{CP}$ and $21 \%$ fat, fed at $441 \mathrm{~g}$ of DM/d; HPLF = high-protein, low-fat MR with $28 \% \mathrm{CP}$ and $20 \%$ fat, fed at $951 \mathrm{~g}$ of DM/d; $\mathrm{HPHF}=$ high-protein, high-fat MR with $27 \% \mathrm{CP}$ and $28 \%$ fat, fed at $951 \mathrm{~g}$ of DM/d; HPHF+ = HPHF fed at 1,431 g of DM/d] for $9 \mathrm{wk}$. The effect of group and diet by group interaction were not significant. The diet by week interaction was significant for IGF-I $(P=0.0441)$; CON had a linear increase in IGF-I over time $(P=0.011)$, whereas the other 3 diets were quadratic over time $(P<0.006)$.

sumed CON varied in a quadratic manner with an apparent nadir ( $20 \pm 4 \mathrm{ng} / \mathrm{mL})$ at wk 4 , whereas IGF-I increased linearly $(P<0.005)$ over time in heifers that consumed the other 3 diets (Figure 1). Heifers on the HPLF, HPHF, and HPHF+ diets did not differ in their IGF-I response to diet.

\section{Diet Effects}

Of the 14 dependent variables analyzed, only plasma glucose, IGFBP-2, and IGFBP-3 were affected by diet. Observed dietary differences were only noted when CON was compared with the average of the other 3 diets. Specifically, neither the addition of fat to the MR (HPLF vs. HPHF) nor increased volume of MR (HPHF vs. $\mathrm{HPHF}+$ ) altered plasma glucose concentration or relative abundance of IGFBP-2 or IGFBP-3 (Figure 2 and Table 3, respectively). Overall, heifers fed CON had lower glucose, greater IGFBP-2, and lower IGFBP3 than the average of the other 3 diets (Figure 2).

\section{Week Effects}

All heifers showed a linear increase in PCV over time $(33 \pm 1.0 \%$ red blood cells at wk 0.5 and $36 \pm 1.0 \%$ red blood cells at wk $9 ; P=0.035$; Table 4 ). Correspondingly, all heifers showed a linear decrease in fecal score over time $(2.0 \pm 0.13$ at wk 0.5 and $1.1 \pm 0.21$ at wk $9 ; P<$
0.001; Table 4). Both insulin and TRI changed over time in a complex pattern (significant linear and quadratic contrast effects). The greatest insulin and TRI concentrations were recorded at wk 0.5 and apparent nadirs were observed at wk 6 for both variables (Table 5). Serum GH concentration decreased in a linear manner from wk 0.5 to wk 9 (Table 5; 8.9 to $4.4 \pm 1.16 \mathrm{ng} / \mathrm{mL}$; $P<0.001)$ in all heifers. Relative abundance of IGFBP2 was affected by week $(P=0.053)$ and was quadratic over time $(P=0.023)$ with the greatest amount of IGFBP-2 observed at wk 5 (Table 3).

\section{Group Effects}

Serum total protein differed by arrival group $(P=$ 0.021). Heifers that arrived at the farm on September 25 (group 3) had greater serum protein compared with heifers arriving on September 10 (group 2) (6.0 vs. 5.7 $\pm 0.08 \mathrm{~g} / \mathrm{dL}$, respectively; Table 5). Serum protein concentrations for heifers that arrived on August 20 (group 1) were not different from the other 2 groups (Table 5).

\section{Correlations}

Overall, PCV was not correlated with fecal score ( $\mathrm{r}=$ $0.13 ; P=0.084)$. Serum IGF-I concentration was positively correlated with relative abundance of IGFBP-3 $(\mathrm{r}=0.40 ; P=0.012)$, negatively correlated with relative 


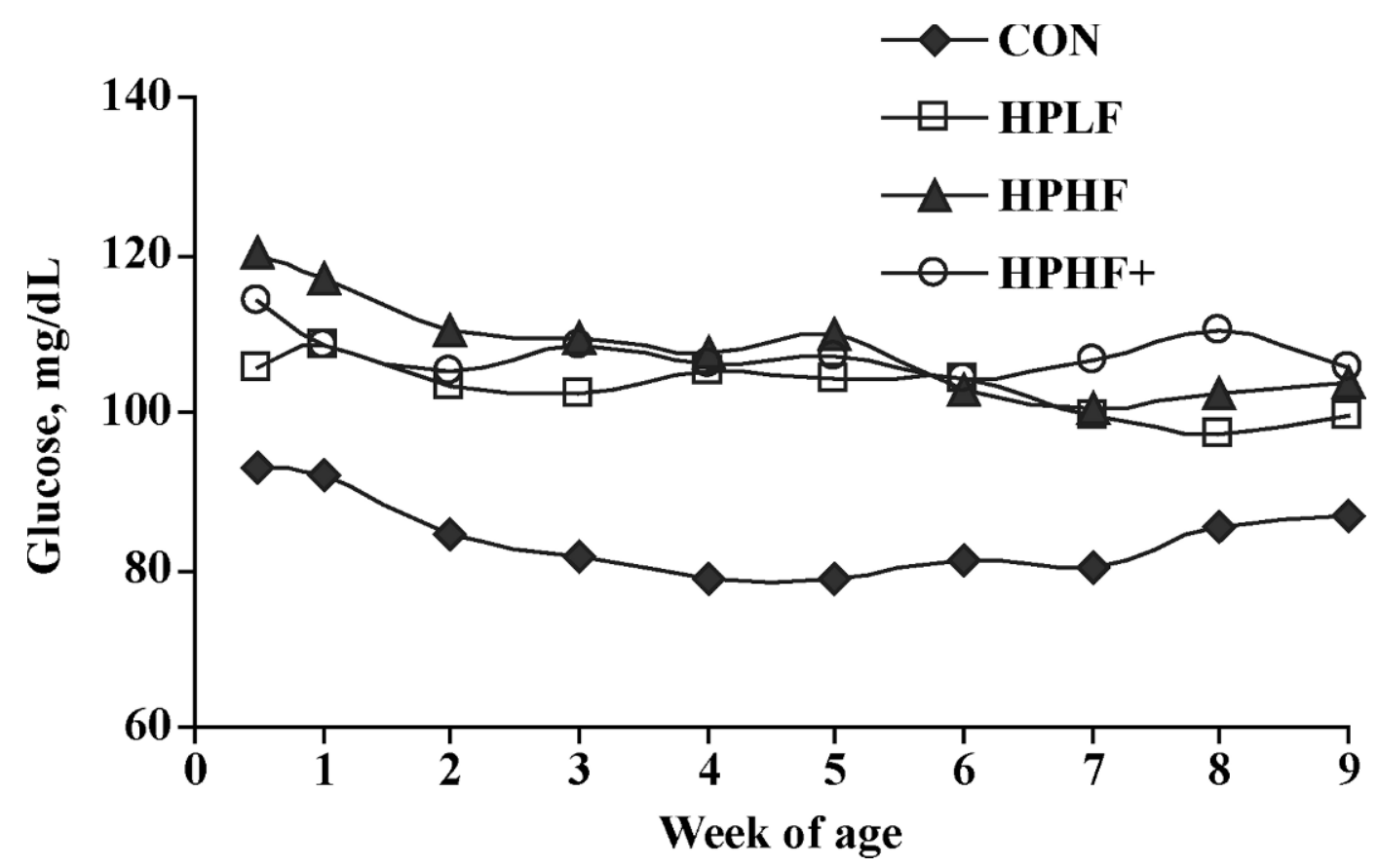

Figure 2. Weekly preprandial plasma glucose concentrations of Holstein heifers fed 1 of 4 treatment diets [CON = control milk replacer (MR) with $20 \% \mathrm{CP}$ and $21 \%$ fat, fed at $441 \mathrm{~g}$ of DM/d; HPLF = high-protein, low-fat MR with $28 \% \mathrm{CP}$ and $20 \%$ fat, fed at $951 \mathrm{~g}$ of DM/d; $\mathrm{HPHF}=$ high-protein, high-fat MR with $27 \% \mathrm{CP}$ and $28 \%$ fat, fed at $951 \mathrm{~g}$ of DM/d; HPHF $+=$ HPHF fed at $1,431 \mathrm{~g}$ of DM/d] for $9 \mathrm{wk}$. The effect of group, week, diet by group interaction, and diet by week interaction were not significant. The main effect of diet and was significant for glucose $(P=0.001$ and $P=0.046)$, respectively. Calves fed CON had lower glucose than the average of the other 3 diets $(P=0.001)$, the addition of fat to MR had no effect on glucose $(P=0.174)$, and increased volume of a high fat MR did not affect glucose $(P=0.830)$.

abundance of IGFBP-2 $(\mathrm{r}=-0.21 ; P=0.001)$, and unrelated to IGFBP-5 and IGFBP-4. Serum GH was not correlated with relative abundance of any IGFBP. Serum GH was negatively correlated with serum IGF-I $(\mathrm{r}=-0.24 ; P=0.01)$.

\section{DISCUSSION}

The objectives of this experiment were to investigate effects of altering dietary protein and energy on concentrations of selected blood metabolites and hormones in Holstein heifers from approximately 1 to 9 wk of age. We analyzed twice-weekly blood samples from heifers that were fed 1 of 4 dietary treatments and examined the effects of diet, week, purchase group, as well as diet by week and diet by group interactions. Treatments were designed to compare the control MR to the average of the other treatment diets; 2 isonitrogenous diets with either 20 or $28 \%$ fat (HPLF vs. HPHF) and an extreme diet to evaluate the effects of a more liberal intake (HPHF vs. HPHF+). As part of our treatment design, all heifers had ad libitum access to starter for the duration of the trial. Surprisingly, only plasma glucose, IGFBP-2, and IGFBP-3 were affected by diet. Furthermore, these differences were not due to the effect of fat in the MR nor to the effect of a more liberal intake of a high-fat MR. Dietary differences were only noted when CON was compared with the average of the other 3 diets; overall, heifers fed CON had lower glucose, greater IGFBP-2, and lower IGFBP-3 than the average of the other 3 diets (Table 3). Additionally, although the main effect of diet cannot be separated for serum IGF-I because there was a significant diet by week interaction, it is evident that heifers on CON displayed a different pattern of IGF-I concentration over time compared with heifers reared on the other 3 diets (Figure 1).

We attribute the diet difference in plasma glucose to increased starter intake in CON. Starter is known to promote rumen development and hence hasten the transition from an essentially monogastric animal (high blood glucose) to a functional ruminant (low blood glucose). However, glucose concentration only tended to be affected by time in our study $(P=0.077)$. We speculate that because CON animals already had lower plasma glucose concentrations than animals on the other $3 \mathrm{di}$ etary treatments at wk 0.5 (likely a reflection of the lower MR intake), this proportional difference was maintained throughout the study, thereby nullifying a treatment by week interaction. Also, our animals were still being fed MR at $9 \mathrm{wk}$ of age; this likely increased plasma glucose and prevented a decline to concentra- 
Table 3. Relative abundance of serum insulin-like growth factor binding protein (IGFBP) profiles in Holstein heifers fed 1 of 4 treatment $\operatorname{diets}^{1}$ and analyzed at 1,5 , and 9 wk of age (repeated sampling within heifer)

\begin{tabular}{|c|c|c|c|c|c|c|c|c|c|}
\hline \multirow[b]{2}{*}{ Item } & \multicolumn{3}{|c|}{ Week } & \multirow[b]{2}{*}{$\mathrm{SEM}^{2}$} & \multicolumn{5}{|c|}{ Test of fixed effects, $P$-value } \\
\hline & 1 & 5 & 9 & & Diet & Group & Week & Diet $\times$ group & Diet $\times$ week \\
\hline \multicolumn{10}{|c|}{ IGFBP-3, RA ${ }^{3}$} \\
\hline $\mathrm{CON}$ & 33 & 37 & 40 & 3.43 & $0.045 \dagger$ & 0.937 & 0.209 & 0.878 & 0.361 \\
\hline HPLF & 38 & 40 & 46 & & & & & & \\
\hline HPHF & 48 & 41 & 43 & & & & & & \\
\hline HPHF+ & 42 & 41 & 45 & & & & & & \\
\hline \multicolumn{10}{|c|}{ IGFBP-2, RA } \\
\hline CON & 22 & 26 & 25 & 1.98 & $0.017 \dagger$ & 0.686 & $0.054 \ddagger$ & 0.103 & 0.498 \\
\hline HPLF & 20 & 25 & 19 & & & & & & \\
\hline HPHF & 17 & 22 & 21 & & & & & & \\
\hline HPHF+ & 19 & 19 & 18 & & & & & & \\
\hline \multicolumn{10}{|c|}{ IGFBP-5, RA } \\
\hline $\mathrm{CON}$ & 17 & 12 & 13 & 2.16 & 0.071 & 0.681 & 0.436 & 0.824 & 0.621 \\
\hline HPLF & 14 & 10 & 11 & & & & & & \\
\hline HPHF & 8 & 11 & 10 & & & & & & \\
\hline HPHF+ & 11 & 10 & 9 & & & & & & \\
\hline \multicolumn{10}{|c|}{ IGFBP-4 (28 kDa), RA } \\
\hline $\mathrm{CON}$ & 11 & 9 & 11 & 1.40 & 0.894 & 0.358 & 0.744 & 0.742 & 0.876 \\
\hline HPLF & 12 & 10 & 11 & & & & & & \\
\hline HPHF & 10 & 11 & 9 & & & & & & \\
\hline HPHF+ & 11 & 11 & 10 & & & & & & \\
\hline \multicolumn{10}{|c|}{ IGFBP-4 (24 kDa), RA } \\
\hline $\mathrm{CON}$ & 18 & 17 & 12 & 1.54 & 0.090 & 0.727 & 0.190 & 0.067 & 0.235 \\
\hline HPLF & 16 & 15 & 13 & & & & & & \\
\hline HPHF & 16 & 17 & 16 & & & & & & \\
\hline $\mathrm{HPHF}+$ & 16 & 18 & 18 & & & & & & \\
\hline
\end{tabular}

${ }^{1} \mathrm{CON}=$ control milk replacer $(\mathrm{MR})$ with $20 \% \mathrm{CP}$ and $21 \%$ fat, fed at $441 \mathrm{~g}$ of DM/d; HPLF = high-protein, low-fat MR with $28 \% \mathrm{CP}$ and $20 \%$ fat, fed at $951 \mathrm{~g}$ of DM/d; HPHF = high-protein, high-fat MR with $27 \%$ $\mathrm{CP}$ and $28 \%$ fat, fed at $951 \mathrm{~g}$ of DM/d; HPHF+ = HPHF fed at 1,431 $\mathrm{g}$ of DM/d.

${ }^{2} \mathrm{SEM}=$ standard error of the mean for diet $\times$ week; highest listed.

${ }^{3} \mathrm{RA}=$ relative abundance, percentage of total IGFBP present

$\dagger$ Contrast results: CON vs. average of other 3 diets, $P<0.009$; quadratic effect of week $(P=0.023)$; HPLF vs. HPHF and HPHF vs. HPHF+ were not significant.

tions typical of fully weaned ruminant animals. Insulin and glucose are intimately linked; however, we did not detect a diet effect on insulin (Table 5). We suspect that our sampling protocol prevented us from being able to detect divergent insulin concentrations in these heifers. Insulin values reported here were obtained after the animals were subjected to a 12 -h fast, were low, and approached the sensitivity limits of the assay. In calves, circulating insulin concentration typically peaks 2 to $4 \mathrm{~h}$ postfeeding; our data in contrast reflect baseline insulin rather than a meal response. Smith et al. (2002) presented plasma insulin concentrations for Holstein bull calves fed a $30 \% \mathrm{CP}, 20 \% \mathrm{MR}$ to achieve target rates of gain of $0.50,0.95$, or $1.40 \mathrm{~kg} / \mathrm{d}$ (low, medium, and high, respectively). They collected blood samples 4 to 6 $\mathrm{h}$ after the morning feeding (from Diaz et al., 2001) and noted that plasma insulin concentrations were distinctly increased with augmented nutrient intake and appeared to sufficiently control circulating glucose (Smith et al., 2002). Had we chosen to sample blood 4 to $6 \mathrm{~h}$ postfeeding, perhaps we would have noted diet differences.
Insulin-like growth factor binding proteins modulate the effects of IGF-I. The IGFBP detected in serum included bands at approximately 44, 40, 34, 31, 29, 28, and $24 \mathrm{kDa}$. Although specific antibodies and deglycosylation techniques were not used to identify individual IGFBP bands, it can be deduced from previous studies that the 44- and 40-kDa bands were 2 different glycosylated forms of IGFBP-3, the $34 \mathrm{kDa}$ band was IGFBP2, IGFBP-5 migrated as a doublet at approximately 29 to $31 \mathrm{kDa}$, and the 24 - and $28-\mathrm{kDa}$ bands were nonglycosylated and glycosylated forms of IGFBP-4, respectively (Cohick et al., 1996; Funston et al., 1996; Roberts et al., 1997). The 44- and 40- kDa bands of IGFBP-3 and the 31 - to $29-\mathrm{kDa}$ bands of IGFBP-5 were not always distinguishable as individual bands on ligand blots. Therefore, IGFBP activity in those regions of ligand blots was analyzed as singular bands. Relative abundance data submitted for statistical analysis included values for IGFBP-3, IGFBP-2, IGFBP-5, and IGFBP-4 (28 $\mathrm{kDa}$ and $24 \mathrm{kDa}$ analyzed separately). Here, we measured an effect of diet on relative abundance of IGFBP-2 and IGFBP-3, but not IGFBP-4 or IGFBP-5. 
Table 4. Effects of diet, ${ }^{1}$ purchase group, and time on packed cell volume and fecal scores in Holstein heifers

\begin{tabular}{|c|c|c|c|c|c|c|c|c|c|c|c|c|c|c|c|c|}
\hline \multirow[b]{3}{*}{ Item } & \multirow{2}{*}{\multicolumn{10}{|c|}{ Week }} & \multirow[b]{3}{*}{$\mathrm{SEM}^{2}$} & \multicolumn{5}{|c|}{ Test of fixed effects, $P$-value } \\
\hline & & & & & & & & & & & & & & & & \\
\hline & 0.5 & 1 & 2 & 3 & 4 & 5 & 6 & 7 & 8 & 9 & & Diet & Group & Week & $\times$ group & $\times$ week \\
\hline $\mathrm{CON}$ & 31 & 32 & 35 & 35 & 36 & 36 & 32 & 32 & 31 & 33 & 2.3 & 0.554 & 0.186 & $0.035 \dagger$ & 0.901 & 0.074 \\
\hline HPLF & 30 & 31 & 33 & 33 & 32 & 32 & 35 & 36 & 35 & 37 & & & & & & \\
\hline HPHF & 32 & 32 & 32 & 33 & 33 & 33 & 33 & 35 & 35 & 35 & & & & & & \\
\hline $\mathrm{HPHF}+$ & 37 & 37 & 35 & 35 & 36 & 36 & 36 & 37 & 35 & 37 & & & & & & \\
\hline HPLF & 1.8 & 1.9 & 3.2 & 1.9 & 1.4 & 1.2 & 1.1 & 1.1 & 1.1 & 1.0 & & & & & & \\
\hline HPHF & 1.7 & 1.6 & 2.4 & 1.9 & 1.2 & 1.4 & 2.0 & 1.3 & 1.4 & 1.1 & & & & & & \\
\hline HPHF+ & 2.2 & 2.3 & 2.6 & 2.3 & 1.4 & 1.8 & 1.8 & 1.9 & 1.8 & 1.5 & & & & & & \\
\hline
\end{tabular}

${ }^{1} \mathrm{CON}=$ control milk replacer $(\mathrm{MR})$ with $20 \% \mathrm{CP}$ and $21 \%$ fat, fed at $441 \mathrm{~g}$ of DM/d; HPLF = high-protein, low-fat MR with $28 \% \mathrm{CP}$ and $20 \%$ fat, fed at $951 \mathrm{~g}$ of DM/d; HPHF = high-protein, high-fat MR with $27 \% \mathrm{CP}$ and $28 \%$ fat, fed at $951 \mathrm{~g}$ of DM/d; HPHF+ = HPHF fed at $1,431 \mathrm{~g}$ of DM/d.

${ }^{2} \mathrm{SEM}=$ standard error of the mean for diet $\times$ week; highest listed.

$\dagger$ Linear effect of week $(P<0.01)$.

Heifers on CON had relatively more IGFBP-2 and less IGFBP-3 than the average of the other 3 diets (Table 3 ).

Dietary treatments of MR, MR + recombinant human IGF-I, or colostrum for $2 \mathrm{~d}$ followed by MR had no effect on IGFBP profiles in the first week of life in neonatal calves (Skaar et al., 1994). Those authors attributed the lack of effect to being a reflection of the minimal effects of dietary IGF-I on circulating IGF-I concentrations in the early days of life (Baumrucker and Blum, 1994) and perhaps low animal numbers in the experiment $(n=16)$. Consistent with the findings of Skaar et al. (1994), we found IGFBP-3 to be the predominant IGFBP in circulation at all times measured and across all dietary treatment groups. In addition to evaluating diet effects on IGFBP profiles in neonatal calves, Skaar et al. (1994) analyzed the ontogeny of IGFBP from birth to $45 \mathrm{wk}$ of age, because changes in IGFBP were observed within the first week of life in all calves regardless of diet. Ligand blot analysis was conducted on plasma from calves that were $1,12,24$, and 45 wk old (infant, juvenile, pre-, and postpubertal, respectively; Skaar et al., 1994). They found that expression of IGFBP-2 peaked at $12 \mathrm{wk}$ with a decrease to $45 \mathrm{wk}$ to a concentration similar to that at wk 1 . The relative abundance of IGFBP-3 continually increased from 1 to 45 wk of age as did IGF-I concentrations (Skaar et al., 1994). In our 9-wk study, relative abundance of IGFBP3 did not change over time (assessed at 3 time points), but IGFBP-2 did (Table 3). Relative abundance of IGFBP-2 was quadratic over time $(P=0.023)$ with the greatest amount of IGFBP-2 observed at wk 5 (Table $3)$. This quadratic trend is consistent with Skaar et al. (1994), who reported a quadratic response of IGFBP-2 concentration over time, although their apparent nadir was observed at wk 12 of life. The exact physiological role of IGFBP-2 is still unclear, but postnatal decreases in concentrations of IGFBP-2 have been noted in other species (Donovan et al., 1989; Owens et al., 1991) and are likely related to IGF-I availability and action during growth and development (Skaar et al., 1994).

In addition to being a positive regulator of body growth, IGF-I has been shown to affect circulating IGFBP profiles (Clemmons et al., 1989; Zapf et al., 1989, 1990). Here, we observed CON to have reduced IGF-I concentration over time compared with the average of the other 3 diets, with a corresponding increase in IGFBP-2 and decrease in IGFBP-3. We found serum IGF-I to be positively correlated with serum IGFBP-3, negatively correlated with IGFBP-2, and unrelated to IGFBP-4 and IGFBP-5.

Endogenous GH is a major regulator of circulating IGF-I. In calves, as in many species, GH concentration decreases during the first year of life at a time when IGF-I and IGFBP-3 both increase. This indicates that factors other than GH control IGF-I and IGFBP-3 concentrations. Concentration of circulating GH was not affected by diet in our calves despite clear dietary effects on IGF-I, IGFBP-3, and IGFBP-2. Circulating GH is known to be secreted in a pulsatile manner throughout the day. Our sampling protocol did not employ multiple blood draws throughout the day to account for this, but values obtained were within the physiologically normal preprandial range for young dairy animals (Hammon et al., 2002; Nussbaum et al., 2002; Quigley et al., 2006). Regardless, our GH data do not suggest an effect of diet (Table 5). We measured a decline in serum GH over time, which is consistent with results of others (Hammon and Blum, 1997; Hammon et al., 2002; Quigley et al., 2006) and is attributed to normal physiological events. In cattle, as with most species, feed restriction 
Table 5. Effects of diet, ${ }^{1}$ purchase group, and time on preprandial blood metabolite concentrations in Holstein heifers

\begin{tabular}{|c|c|c|c|c|c|c|c|c|c|c|c|c|c|c|c|c|}
\hline \multirow[b]{2}{*}{ Item } & \multicolumn{10}{|c|}{ Week } & \multirow[b]{2}{*}{$\mathrm{SEM}^{2}$} & \multicolumn{5}{|c|}{ Test of fixed effects, $P$-value } \\
\hline & 0.5 & 1 & 2 & 3 & 4 & 5 & 6 & 7 & 8 & 9 & & Diet & Group & Week & Diet $\times$ group & Diet $\times$ week \\
\hline \multicolumn{17}{|c|}{ Insulin, ng/mL } \\
\hline CON & 0.35 & 0.27 & 0.17 & 0.17 & 0.18 & 0.19 & 0.17 & 0.19 & 0.19 & 0.21 & 0.06 & 0.783 & 0.121 & $<0.001 \dagger \dagger$ & 0.958 & 0.440 \\
\hline HPLF & 0.43 & 0.35 & 0.19 & 0.16 & 0.15 & 0.16 & 0.15 & 0.16 & 0.20 & 0.18 & & & & & & \\
\hline HPHF & 0.49 & 0.44 & 0.23 & 0.22 & 0.20 & 0.17 & 0.15 & 0.15 & 0.16 & 0.26 & & & & & & \\
\hline $\mathrm{HPHF}+$ & 0.35 & 0.26 & 0.16 & 0.20 & 0.17 & 0.17 & 0.15 & 0.19 & 0.25 & 0.24 & & & & & & \\
\hline \multicolumn{17}{|c|}{ Triglycerides, mmol/L } \\
\hline CON & 0.20 & 0.17 & 0.18 & 0.17 & 0.16 & 0.16 & 0.15 & 0.19 & 0.21 & 0.20 & 0.03 & 0.433 & 0.074 & $<0.001 \dagger \dagger$ & 0.505 & 0.060 \\
\hline HPLF & 0.25 & 0.19 & 0.18 & 0.15 & 0.10 & 0.13 & 0.12 & 0.12 & 0.12 & 0.10 & & & & & & \\
\hline HPHF & 0.30 & 0.28 & 0.18 & 0.14 & 0.12 & 0.11 & 0.16 & 0.13 & 0.13 & 0.15 & & & & & & \\
\hline $\mathrm{HPHF}+$ & 0.26 & 0.21 & 0.15 & 0.15 & 0.15 & 0.16 & 0.10 & 0.10 & 0.11 & 0.12 & & & & & & \\
\hline \multicolumn{17}{|c|}{ Growth hormone, ng/mL } \\
\hline CON & 11.7 & 12.2 & 12.4 & 6.2 & 6.5 & 7.6 & 5.9 & 5.0 & 3.2 & 5.7 & 3.06 & 0.278 & 0.736 & $0.012 \dagger$ & 0.755 & 0.772 \\
\hline HPLF & 9.7 & 10.7 & 12.5 & 5.6 & 5.8 & 8.7 & 11.3 & 6.2 & 4.0 & 3.8 & & & & & & \\
\hline HPHF & 7.4 & 7.6 & 4.6 & 4.4 & 5.1 & 8.4 & 8.5 & 2.3 & 4.1 & 5.1 & & & & & & \\
\hline $\mathrm{HPHF}+$ & 6.8 & 10.1 & 3.4 & 6.8 & 7.0 & 3.2 & 4.5 & 3.4 & 3.8 & 2.9 & & & & & & \\
\hline \multicolumn{17}{|c|}{ Serum protein, g/dL } \\
\hline CON & 5.8 & 5.8 & 5.8 & 5.9 & 5.8 & 5.7 & 5.8 & 6.1 & 6.3 & 6.1 & 0.19 & 0.401 & $0.021^{3}$ & 0.210 & 0.936 & 0.528 \\
\hline HPLF & 5.5 & 5.6 & 5.6 & 5.6 & 5.7 & 5.8 & 5.6 & 5.8 & 5.9 & 5.7 & & & & & & \\
\hline HPHF & 5.8 & 5.9 & 5.8 & 5.7 & 5.5 & 5.9 & 6.0 & 5.9 & 6.0 & 6.3 & & & & & & \\
\hline \multirow{2}{*}{\multicolumn{17}{|c|}{ NEFA, mmol/L }} \\
\hline & & & & & & & & & & & & & & & & \\
\hline $\mathrm{CON}$ & 0.45 & 0.50 & 0.42 & 0.40 & 0.39 & 0.31 & 0.29 & 0.27 & 0.30 & 0.34 & 0.05 & 0.242 & 0.430 & 0.067 & 0.675 & 0.396 \\
\hline HPLF & 0.36 & 0.38 & 0.43 & 0.38 & 0.33 & 0.35 & 0.29 & 0.36 & 0.33 & 0.41 & & & & & & \\
\hline HPHF & 0.35 & 0.36 & 0.44 & 0.40 & 0.40 & 0.39 & 0.41 & 0.37 & 0.37 & 0.42 & & & & & & \\
\hline $\mathrm{HPHF}+$ & 0.49 & 0.46 & 0.44 & 0.36 & 0.43 & 0.42 & 0.36 & 0.40 & 0.38 & 0.41 & & & & & & \\
\hline \multicolumn{17}{|c|}{ Plasma urea $\mathrm{N}, \mathrm{mg}$ of urea $\mathrm{N} / \mathrm{dL}$} \\
\hline $\mathrm{CON}$ & 8.5 & 8.7 & 6.4 & 7.7 & 7.2 & 7.8 & 7.6 & 8.4 & 7.0 & 7.2 & 1.33 & 0.581 & 0.192 & 0.155 & 0.784 & 0.735 \\
\hline HPLF & 7.0 & 7.1 & 7.4 & 7.8 & 8.1 & 9.1 & 7.9 & 7.1 & 7.1 & 8.3 & & & & & & \\
\hline HPHF & 5.9 & 5.7 & 5.1 & 9.1 & 7.7 & 6.6 & 6.4 & 6.7 & 6.3 & 7.9 & & & & & & \\
\hline $\mathrm{HPHF}+$ & 6.3 & 6.6 & 6.3 & 6.6 & 7.7 & 8.1 & 8.1 & 8.2 & 7.6 & 9.7 & & & & & & \\
\hline
\end{tabular}

${ }^{1} \mathrm{CON}=$ control milk replacer $(\mathrm{MR})$ with $20 \% \mathrm{CP}$ and $21 \%$ fat, fed at $441 \mathrm{~g}$ of DM/d; HPLF = high-protein, low-fat MR with $28 \% \mathrm{CP}$ and $20 \%$ fat, fed at $951 \mathrm{~g}$ of DM/d; $\mathrm{HPHF}=$ high-protein, high-fat MR with $27 \% \mathrm{CP}$ and $28 \%$ fat, fed at $951 \mathrm{~g}$ of DM/d; HPHF+ = HPHF fed at 1,431 g of DM/d.

${ }^{2} \mathrm{SEM}=$ standard error of the mean for diet $\times$ week; highest listed.

${ }^{3}$ Least squares means for groups 1 to 3 were as follows: $5.8,5.7$, and $6.0 \pm 0.08 \mathrm{~g} / \mathrm{dL}$, respectively.

$\dagger$ Linear effect of week; †quadratic effect of week. 
usually causes an increase in circulating GH. Had we restricted the starter intake in $\mathrm{CON}$ we would have likely seen an increase in GH concentration in those animals.

Although perhaps not an ideal model for the heifer calf but worth mention, the model of Vicini et al. (1991) showed that dietary restriction or periods of negative energy balance are associated with increased circulating IGFBP-2 and decreased IGFBP-3 in ruminants. Similarly, in a study designed to evaluate nutritional influences on reproductive function in beef cattle, Roberts et al. (1997) noted that cows that failed to resume cycling postpartum had lower circulating IGF-I, greater amounts of IGFBP-2, and lesser amounts of IGFBP-3 at wk 2 postpartum compared with cows that resumed cycling during that time. Nutritional suppression of the GH-IGF-I axis in CON is probable and therefore this axis likely alters circulating IGFBP-2 and IGFBP-3. The physiological significance of IGFBP in serum, especially as it relates to animals reared on CON, remains to be determined. One proposition is that changes in the GH-IGF-I-IGFBP axis occur in response to nutritional stress and that these changes provide a signal to the hypothalamus to perceive changes in metabolic status (Roberts et al., 1997). It remains to be determined what divergent roles, if any, IGFBP-2 and IGFBP-3 played in $\mathrm{CON}$ compared with the other 3 dietary treatments.

The diets used in this experiment were designed to differ in energy and protein content; therefore, we thought that markers for protein and fat metabolism (PUN, NEFA, TRI) would be affected by diet, but they were not (Table 5). Feeding a diet that supplies more protein than the animal can utilize should result in elevated PUN. Here, PUN was not affected by diet or by any other model effect tested. Terosky et al. (1997), Smith et al. (2002), and Bartlett et al. (2006) also noted no change in PUN over time or with respect to imposed dietary treatments, and reported PUN concentrations similar to ours. More $\mathrm{N}$ was supplied to heifers fed $\mathrm{HPHF}+$ than to those fed HPHF, which was the goal of the treatment design. A companion paper (Hill et al., 2008) showed that heifers fed the HPHF+ diet consumed $15.2 \mathrm{~g} / \mathrm{d}$ more $\mathrm{N}$ than those fed HPHF, but $\mathrm{N}$ retention was unchanged because most of the excess $\mathrm{N}$ was excreted in urine. This agrees with PUN data and suggests that liberal intake of a high-protein, high-fat MR is not recommended for practical purposes and results in excess nutrients being lost to the environment. Bascom et al. (2007), Tikofsky et al. (2001), and Bartlett et al. (2006) have all reported elevated NEFA in bull calves fed high-fat MR compared with cohorts fed MR with lower fat, and this is attributed to the fat source of the high-fat MR (edible lard as opposed to milk fat). The fat source was the same for all MR used in this experiment (edible lard), which might explain why no differences in NEFA were detected (Table 5). Additionally, elevated NEFA are a hallmark sign of adipose tissue catabolism. Because NEFA were unaffected by diet, this suggests that feed intake in all dietary treatment groups provided sufficient energy supply preceding the next MR meal, even in CON. Last, because the MR feeding frequency was the same for all dietary treatments in this experiment, the lack of diet effects on plasma TRI (Table 5) implies little, if any, difference among treatments on frequency of starter consumption by our heifers. Pancreatic lipase activity and efficiency of TRI clearance also affect plasma TRI concentrations. Plasma TRI was similar and deposition of body fat greater (Hill et al., 2008) when heifers were fed HPHF+ compared with HPHF. These observations indicate that pancreatic lipase activity was sufficient to facilitate absorption of a substantial amount of the additional dietary fat and this addition of dietary fat did not overwhelm TRI clearance.

A secondary objective of this experiment was to examine the relationship between concentrations of metabolites and hormones with overall calf performance. We chose to use PCV and fecal scores for this purpose. Packed cell volumes reported here are similar to those reported elsewhere for calves of this age (Terosky et al., 1997; Lesmeister et al., 2004; Lesmeister and Heinrichs, 2005). All heifers showed a linear increase in PCV and a linear decrease in fecal score over time (Table 4). Overall, PCV was not correlated with fecal score ( $\mathrm{r}=$ $0.13 ; P=0.084)$. We speculated that PCV and fecal score would be positively correlated, considering that heifers with watery feces (fecal scores of 3 to 4) are more likely to be dehydrated and therefore have greater PCV. The electrolyte therapy used in this study may have prevented dehydration in scouring heifers, thereby keeping PCV within the physiologically normal range for preweaned heifers.

Failure of passive transfer, assessed at approximately $2 \mathrm{~d}$ of age, was detected in 5 calves (22\%) despite implementation of a colostrum management protocol (Table 2). Calves with failure of passive transfer were dispersed between group 2 (CON, HPLF, and HPHF+) and group 3 (CON and HPHF), with no difference in IgG concentration detected between the 3 purchase groups. Because calves with failure of passive transfer were present in all dietary treatment groups, our results are not biased by IgG status. Serum protein differed by purchase group in our animals (Table 5); however, when wk 0.5 samples were analyzed separately with IgG data, serum protein was not affected by diet, group, or their interaction (data not shown). Moreover, wk 0.5 serum protein values were positively correlated with IgG concentration $(\mathrm{r}=0.528 ; P=0.012)$. Serum protein 
concentration did not change over time or with diet in these heifers, but was still affected by purchase group (Table 5). The third group of heifers had fewer general health ailments (data not shown) than the other 2 groups and it is speculated that the increased serum total protein concentration reflects this result. Because most of the protein found in serum is albumin, we can infer that hepatic synthesis of albumin was not affected by diet in this experiment, but appears to have been affected by calf health. Similar to our findings, Terosky et al. (1997) noted no change in serum protein over time or with dietary treatment in similarly aged bull calves. Conversely, Bartlett et al. (2006) noted differences in concentration of total protein in plasma for calves fed varying amounts of dietary $\mathrm{CP}$ (14 to $26 \%$ ) in MR at 1 of 2 intake levels (1.25 or $1.75 \%$ of $\mathrm{BW}$ ) and attributed these differences to protein malnutrition in the animals with lower plasma protein concentrations. Because we detected no differences in serum protein with diet, we can infer that protein malnutrition was not experienced in this experiment.

\section{CONCLUSIONS}

Preprandial blood metabolite and hormone concentrations in young heifers varied more with age than with imposed dietary treatments. These temporal changes reflect the transition from an essentially monogastric animal to a functional ruminant. With the exception of glucose, IGF-I, and IGFBP-2 and IGFBP3 , the blood variables measured here were not influenced by treatment diet composition. The IGF-I-GHIGFBP axis requires further study in heifers to deduce effects of nutrition on hypothalamic regulation of metabolism. We expected to see more treatment differences in concentrations of metabolites involved with protein and fat metabolism. It is likely that the diets used in this study were not diverse enough in composition to warrant such changes or the efficiency of use of absorbed protein and fat was not different in these animals.

\section{ACKNOWLEDGMENTS}

The authors would like to thank Aaron Cornman, Michael Guard, Christopher Lily, and Shane Martin for assistance feeding, weighing, and harvesting heifers and Davina Campbell, Joby Cyriac, Brandy Huderson, Agustin Rius, and Bisi Velayudhan for assistance in bleeding heifers. Sincere thanks are extended to Patricia Boyle and Greta Moyer for providing excellent technical assistance in the lab and to Mark Hanigan for his constructive advice. The financial assistance and donation of milk replacers by Land O'Lakes Inc. Animal
Milk Products Co. (Arden Hills, MN) is greatly appreciated. Gratitude is also expressed to APC Inc. (Ames, IA) and Nouriche Nutrition Ltd. (Lake St. Louis, MO) for supplying the Gammulin and electrolytes used in this study. K. M. Daniels is the recipient of a John Lee Pratt Fellowship in Animal Nutrition and would like to thank the Pratt Foundation for financial support.

\section{REFERENCES}

Bartlett, K. S., F. K. McKeith, M. J. VandeHaar, G. E. Dahl, and J. K. Drackley. 2006. Growth and body composition of dairy calves fed milk replacers containing different amounts of protein at two feeding rates. J. Anim. Sci. 84:1454-1467.

Bascom, S. A., R. E. James, M. L. McGilliard, and M. Van Amburgh. 2007. Influence of dietary fat and protein on body composition of Jersey bull calves. J. Dairy Sci. 90:5600-5609.

Baumrucker, C. R., and J. W. Blum. 1994. Effects of dietary recombinant human insulin-like growth factor-I on concentrations of hormones and growth factors in the blood of newborn calves. J. Endocrinol. 140:15-21.

Berry, S. D. K., R. D. Howard, P. M. Jobst, H. Jiang, and R. M. Akers. 2003. Interactions between the ovary and the local IGF-I axis modulate mammary development in prepubertal heifers. J. Endocrinol. 177:295-304.

Breier, B. H., P. D. Gluckman, and J. J. Bass. 1988. Plasma concentrations of insulin-like growth factor-I and insulin in the infant calf: Ontogeny and influence of altered nutrition. J. Endocrinol. 119:43-50.

Brown, E. G., M. J. VandeHaar, K. M. Daniels, J. S. Liesman, L. T. Chapin, J. W. Forrest, R. M. Akers, R. E. Pearson, and M. S. Weber Nielsen. 2005b. Effect of increasing energy and protein intake on mammary development in heifer calves. J. Dairy Sci. 88:595-603.

Brown, E. G., M. J. VandeHaar, K. M. Daniels, J. S. Liesman, L. T. Chapin, D. H. Keisler, and M. S. Weber Nielsen. 2005a. Effect of increasing energy and protein intake on body growth and carcass composition of heifer calves. J. Dairy Sci. 88:585-594.

Chaney, A. L., and E. P. Marbach. 1962. Modified reagents for determination of urea and ammonia. Clin. Chem. 8:130-132.

Clemmons, D. R., J. P. Thissen, M. Maes, J. M. Ketelslegers, and L. E. Underwood. 1989. Insulin-like growth factor-I (IGF-I) infusion into hypophysectomized or protein-deprived rats induces specific IGF-binding proteins in serum. J. Endocrinol. 125:2967-2972.

Cohick, W. S., J. D. Armstrong, M. D. Whitcare, M. C. Lucy, R. W. Harvey, and R. M. Campbell. 1996. Ovarian expression of insulinlike growth factor-I (IGF-I), IGF binding proteins, and growth hormone $(\mathrm{GH})$ receptor in heifers actively immunized against GH-releasing factor. Endocrinology 137:1670-1677.

Diaz, M. C., M. E. Van Amburgh, J. M. Smith, J. M. Kelsey, and E. L. Hutten. 2001. Composition of growth of Holstein calves fed milk replacer from birth to 105-kilogram body weight. J. Dairy Sci. 84:830-842.

Donovan, S. M., Y. Oh, H. Pham, and R. G. Rosenfeld. 1989. Ontogeny of serum insulin-like growth factor binding proteins in the rat. J. Endocrinol. 125:2621-2627.

Funston, R. N., G. E. Seidel Jr., J. Klindt, and A. J. Roberts. 1996. Insulin-like growth factor I and insulin-like growth factor-binding proteins in bovine serum and follicular fluid before and after the preovulatory surge of luteinizing hormone. Biol. Reprod. 55:1390-1396.

Hammon, H., and J. W. Blum. 1997. The somatotropic axis in neonatal calves can be modulated by nutrition, growth hormone, and LongR3-IGF-I. Am. J. Physiol. Endocrinol. Metab. 36:E130-E138.

Hammon, H. M., G. Schiessler, A. Nussbaum, and J. W. Blum. 2002. Feed intake patterns, growth performance, and metabolic and endocrine traits in calves fed unlimited amounts of colostrum and milk by automate, starting in the neonatal period. J. Dairy Sci. 85:3352-3362. 
Hill, S. R., K. F. Knowlton, K. M. Daniels, R. E. James, R. E. Pearson, A. V. Capuco, and R. M. Akers. 2008. Effects of milk replacer composition on growth, nutrient excretion, and body composition in preweaned Holstein heifers. J. Dairy Sci. doi:10.3168/ jds.2007-0860

Lesmeister, K. E., and A. J. Heinrichs. 2005. Effects of adding extra molasses to a texturized calf starter on rumen development, growth characteristics, and blood parameters in neonatal dairy calves. J. Dairy Sci. 88:411-418.

Lesmeister, K. E., A. J. Heinrichs, and M. T. Gabler. 2004. Effects of supplemental yeast (Saccharomyces cerevisiae) culture on rumen development, growth characteristics, and blood parameters in neonatal dairy calves. J. Dairy Sci. 87:1832-1839.

McFadden, T. B., T. E. Daniel, and R. M. Akers. 1990. Effects of plane of nutrition, growth hormone and unsaturated fat on growth hormone, insulin and prolactin receptors in prepubertal lambs. J. Anim. Sci. 68:3180-3189.

Meyer, M. J., A. V. Capuco, D. A. Ross, L. M. Lintault, and M. E. Van Amburgh. 2006a. Developmental and nutritional regulation of the prepubertal heifer mammary gland: I. Parenchyma and fat pad mass and composition. J. Dairy Sci. 89:4289-4297.

Meyer, M. J., A. V. Capuco, D. A. Ross, L. M. Lintault, and M. E. Van Amburgh. 2006b. Developmental and nutritional regulation of the prepubertal bovine mammary gland: II. Epithelial cell proliferation, parenchymal accretion rate, and allometric growth. J. Dairy Sci. 89:4298-4304.

Nussbaum, A., G. Schiessler, H. M. Hammon, and J. W. Blum. 2002. Growth performance and metabolic and endocrine traits in calves pair-fed by bucket or by automate starting in the neonatal period. J. Anim. Sci. 80:1545-1555.

Owens, P. C., M. A. Conlon, R. G. Campbell, R. J. Johnson, R. King, and F. J. Ballard. 1991. Developmental changes in growth hormone, insulin-like growth factors (IGF-I and IGF-11) and IGFbinding proteins in plasma of young growing pigs. J. Endocrinol. 128:439-447.

Quigley, J. D., III, L. A. Caldwell, G. D. Sinks, and R. N. Heitmann. 1991. Changes in blood glucose, nonesterified fatty acids, and ketones in response to weaning and feed intake in young calves. J. Dairy Sci. 74:250-257.

Quigley, J. D., III, T. A. Wolfe, and T. H. Elsasser. 2006. Effects of additional milk replacer feeding on calf health, growth, and selected blood metabolites in calves. J. Dairy Sci. 89:207-216.

Roberts, A. J., R. A. Nugent III, J. Klindt, and T. G. Jenkins. 1997. Circulating insulin-like growth factor binding proteins, growth hormone, and resumption of estrus in postpartum cows subjected to dietary energy restriction. J. Anim. Sci. 75:1909-1917.
Sejrsen, K., and S. Purup. 1997. Influence of prepubertal feeding level on milk yield potential of dairy heifers: A review. J. Anim. Sci. 75:828-835.

Sejrsen, K., S. Purup, M. Vestergaard, and J. Foldager. 2000. High body weight gain and reduced bovine mammary growth: Physiological basis and implications for milk yield potential. Domest. Anim. Endocrinol. 19:93-104.

Sharma, B. K., M. J. VandeHaar, and N. K. Ames. 1994. Expression of insulin-like growth factor-I in cows at different stages of lactation and in late lactation cows treated with somatotropin. J. Dairy Sci. 77:2232-2241.

Skaar, T. C., C. R. Baumrucker, D. R. Deaver, and J. W. Blum. 1994 Diet effects and ontogeny of alterations of circulating insulin-like growth factor binding proteins in newborn dairy calves. J. Anim. Sci. 72:421-427.

Smith, J. M., M. E. Van Amburgh, M. C. Diaz, M. C. Lucy, and D. E. Bauman. 2002. Effect of nutrient intake on the development of the somatotropic axis and its responsiveness to GH in Holstein bull calves. J. Anim. Sci. 80:1528-1537.

Terosky, T. L., A. J. Heinrichs, and L. L. Wilson. 1997. A comparison of milk protein sources in diets of calves up to eight weeks of age. J. Dairy Sci. 80:2977-2983.

Tikofsky, J. N., M. E. Van Amburgh, and D. A. Ross. 2001. Effect of varying carbohydrate and fat content of milk replacer on body composition of Holstein bull calves. J. Anim. Sci. 79:2260-2267.

Vicini, J. L., F. C. Buonomo, J. J. Veenhuizen, M. A. Miller, D. R. Clemmons, and R. J. Collier. 1991. Nutrient balance and stage of lactation affect responses of insulin, insulin-like growth factors I and II, and insulin-like growth factor-binding protein 2 to somatotropin administration in dairy cows. J. Nutr. 121:1656-1664.

Weatherburn, M. W. 1967. Phenol-hypochlorite reaction for determination of ammonia. Anal. Chem. 36:971-974.

Weber, M. S., S. Purup, M. Vestergaard, S. E. Ellis, J. ScndergardAndersen, R. M. Akers, and K. Sejrsen. 1999. Contribution of insulin-like growth factor (IGF)-I and IGF-binding protein-3 to mitogenic activity in bovine mammary extracts and serum. J. Endocrinol. 161:365-373.

Zapf, J., C. Hauri, M. Waldvogel, E. Futo, H. Hasler, K. Binz, H. P. Guler, C. Schmid, and E. R. Froesch. 1989. Recombinant human insulin-like growth factor I induces its own specific carrier protein in hypophysectomized and diabetic rats. Proc. Natl. Acad. Sci. USA 86:3813-3817.

Zapf, J., C. Schmid, H. P. Guler, M. Waldvogel, C. Hauri, E. Futo, P. Hossenlopp, M. Binoux, and E. R. Froesch. 1990. Regulation of binding proteins for insulin-like growth factors (IGF) in humans. Increased expression of IGF binding protein 2 during IGF I treatment of healthy adults and in patients with extrapancreatic tumor hypoglycemia. J. Clin. Invest. 86:952-961. 